\title{
THE TRAP OF ANACRONISM IN THE SOCIAL SCIENCES
}

\section{Murat \$EKER}

The constitutions of so many states studied by Aristoteles proves that cross-cultural work on human societies is not a new field. And in our times, the importance of such work for comparative and (hopefully) progressive results is monumentous. Aiming to deal. with a problem in doing cross-cultural work, this paper is not by any means, intended to discourage such studies. In fact, the main idea is to encourage such work by pointing out to the methodological procedures resulting from societal differences. Another integrated subject in the fied, the necessity of a value free sociology is for the time being left out of the paper to clear the focal point.

To start with an example from a famous play;

During the proceedings, Brutus and his friends have been observed in plotting against Caesar, it is after midnight and Trebonius has just spoken, "(Clock strikes

"BRUTUS

"Peace, count the clock.

"CASSIUS

"The clock hath stricken three.

\section{"TREBONIUS}

"T is time to part"*

Thus is an example of anacronism introduced into a literary work, for we know historically that, in the times of Julius Caesar there were no grandfather clocks. Forgivable in a literary work, as a detail in a play, anacronism can be seriously misleading, (and not always so obvious) in social scientific research.

* William Shakespeare, Julius Ceasar, H.M. Hulme-Ed., Green and Co. Ltd., London, 1965, 2nd ed., Act. 2, Scene I. P. 71. 
The problem arises from the cultural differences of societies, both among themselves and historically in the same society. From Anthropologists to Legal Sociologists have long discovered that intersocietal similarities in Culture are mainly coincidental, probably resulting from the same necessity of social existance. Even, should this not be so, and as in the case of the difference historically in any one society, when it is not so, the reality of social change, which is the result of many overlapping factors, ensures the difference. Sociology of Religion confirms intersocietal difference in religious social functions, even between societies having the same religion.

The twofold danger in approaching another society is, first carrying there the value judgements of one's own society, thus declaring for example the Hawaian natives "immoral", and seccond, in a more sinister sickness of aproach, taking the other societies facts as they are, without personal values but comparing them with one's own society as they are, with one's own societal values. This rude and raw comparison is anacronism.

Anachronism, generally results from hasty research, carried out in a country not quite understood by the researcher. Thus the researcher either omits facts, or classifies them under misfitting labels, sometimes like, "odd customs". While the author is not sure about the liberal use of functionalism, he can not but agree with Malinowski when he says, "... there are factors and forces which compel man, individually and collectively, to behave in a way specific to each given culture in matters which transcend and modify mere biological impulses and the direct influence of environmental conditions. Each culture develops in the course of its historical evolution systems of, knowledge, values -conomic, social and aesthetic - and at last but not least, beliefs and convictions based on supernatural revelation. Each cultural value or imperative determines conduct in matters as elementary as the preferences for certain types of food and drink; in the responses to the drive of sex and the desire for family life; in the sense of honor, and of right and wrong; in the type and range of amusements; and in objects regarded as culturally valuable."* The researcher can not omit these factors. Neither can he let his own 'preferences', 'responses' or any other values, supersede knowingly or othervise, those of the researced.

In a manual prepared by The World Federation for Mental Health and edited by Margaret Mead, the warnings in a technical but similar field are interesting:

\footnotetext{
- Malinowski, Bronislaw, The Dynamics of Culture Change, Yale University Press. 1961, P. 77.
} 
"There are two aspects of the problem of technical change seen from the point of view of mental health: mental-health services of mental health as the generalized goal of technical change. Technical change in its narrow sense includes not only technical advice on agriculture or animal-breeding, but also improved medical and public-health services, and these in turn are specifically and technically concerned with problems of the cure and prevention of mental illness and the cultivation of mental health. On a wider front, it may be said that the goal of technical change is to give to people of each country a way of life within which greater mental health may be achieved for all the members of that society.

"Superficially, these two approaches may appear as separate. Under the heading of mental-health services fall such matters as the location of the mentally ill, the establishment of basic statistical data on the incidence of different types of mental illness, the exploration of the best methods by which those who are seriously ill can be treated, the way in which cultural factors must be taken into account in determining which forms of treatment are practical and likely to give results. These are the problems which face those world-wide governmental and voluntary agencies attempting to get a picture of the conditions of mental health in the world and to develop standards for the guidance of new international and local agencies. Under this heading comes the question of diagnosis: how to distinguish between some unfamiliar but culturally conventional forms of behaviour-such as seeing visions, hearing voices, believing that other people are killing one by magic-and symptoms of genuine mental illness. Even in Western countries where psychiatry is highly developed, the criteria are inadequate for distinguishing between mental illness and behaviour which is bizarre because the cultural context is not known-as when a former member of a secret society which operates by periodic assassination of members of a rival society informs the police in an American city that people are trying to kill him, and, until his nationality and society membership are known, is diagnosed as dangerously paranoid. Periods of customary religious fasting and withdrawal from all social intercourse may be very difficult to distinguish from attacks of catatonic schizophrenia. It may even be found that members of a society customarily fall into a benign deep stupor when they meet with frustrating or frightening situations-as is the case for the Balinese. Where psychiatry has existed side by side with religion for a long period, as in the West, a mutual accommodation takes place and it is possible for the religious leadership to develop criteria which will distinguish between individuals who may be regarded as supernaturally blessed, but not mentally unbalanced, and individuals whose mental illness has a high religious content. In introducing psychiatric practices into countries in which no such modus 
vivendi between religion and psychiatry has been worked out, a great deal of preliminary work needs to be done to establish criteria for diagnosis. This will be found to be true not only for such complex matters as trance and vision experience, but also for such simple matters as the accurate reporting on and localization of pain, or the evaluation of the psychogenic component in the healing of a wound. Among some peoples wound-healing is regularly delayed and a failure to heal will be significant only if it occurs beyond these delayed limits; among others, the rate of healing of a particular wound may have to be evaluated against a very high customary healing rate. So the whole range of somatic symptoms which modern psychiatry assumes to have, at least in some cases, a strong psychogenic component, have to be explored within the cultural setting before they can be evaluated diagnostically.

"When there is any attempt to go beyond the diagnosis of psychotic states or of specific somatic symptoms to the diagnosis and treatment of neurosis, even greater caution is needed. Behaviour which would be regarded in the Western world as a sign of a highly developed obsessional neurosis, may be quite conventional in another culture-as, for example, ritual cleanliness or periods of extreme sexual licence. When it is also necessary to take inter-personal patterns of relationship into account, such as the degree of dependency or hostility which the child feels for the parent, even greater knowledge of the culture is needed. There are societies, for example, in which the only way in which the son can leave home is by having a terrific quarrel with his father; what would appear to be highly unbalanced and dangerously hostile behaviour if seen only once in a single individual, will be found-when the whole cultural situation is known-to be a customary, dramatic way of breaking ties of dependency between one generation and another. Societies differ very much as to how and when the younger generation is weaned from the parent generation. Mothers may be permissive and permit a high degree of physical dependency, which is then followed by a harsh and sudden separation and an initiatory ceremony of some sort: being sent to boarding-school, being put on a régime of strict frugality and abstention from all gentleness, etc. The clinging affectionate behaviour of a boy of 12 to his mother cannot be evaluated as unusual and a sign of neurotic needs-on his or her part or both their parts-until the rest of the social maturation pattern is know."*

The result of anacronism is mislabeling historical or contemporary evidence and thus faulty explanation or in some cases falling into a

* Mead, Margaret (ed.), Cultural Patterns and Technical Change, New American Library, 7th printing, 1861, P. 263-265. 
complete lack of explanation. In explaining these, example within the author's reach and knowledge will be given.

While working upon rural workers in Turkey, the author was at first confronted with the task of defining the rural worker. Prior research had titled various forms of rural work as the work of the rural worker. Among these were, the kind of semi-feudal work performed in a traidtional setting. Endless titles for such workers had been given, all collected from various regions of the country and from history. Some researchers had even labelled the share-croppers as rural workers. Going from the data only, the author could identify in the researched area the rural worker only as the wage-earning person working in a modern setting. Thus the cross-cultural comparison of a group of people on the basis of national integration was possible.

Another set of examples are taken from the Turkish book of Adam Şenel, translated as The Critical History of Rightist Thought.* Although in the Introduction, Şenel defines "Rightist" as the "defender of inequality", this stil leaves room for critisism which does not involve this paper. But using the label "rightist", which is the product of the French Revolution, for the philosophers going to as far as the Ancient Greece is an example of anachronism.** Should the reader of his book alter the title "Rightist" to "Conservative", bold anachronism still exists in other places. Darwinism for example, may have been used by conservatives or rightists, but it itself is not rightist.*** To take another example, Abraham Lincoln is stated as rightist and anti-black.**** The reader of this paper will hopefully appriciate that, isolated quotations can not by themselves place. a man of a monumental work in history.

An example of lack of explanation is obtained from Raphael Patai when he naievely asks the reason for the Arabs' hatred for the West and not the Turks.

He states:

"Finally, in discussing the psychological motivations of Arab hatred of the West, the question must be asked, Why did the Arabs single out the West as the object of their hate rather than Turkey? After all, the Arab lands were exposed to Western incursion and domination for about a hundred years only; whereas the Turks ruled the Arab world for four

\footnotetext{
* Senèl, Adam, Sağcı Düşünüşlin Kritik Tarihi, Doğan Yayınevi, Ankara, 1968.

$\star$ Ibid, P. 116.

*** Ibid, P. 126.

*** Ibid, P. 221.
} 
centuries. Moreover, the Turkisk yoke weighed much more heavily on the necks of the Arabs than did that of the European colonial powers. Economically, the Turks bled the Arab lands white. They considered the Arabs subject peoples whose only roles in life were to pay heavy taxes to the.Turks and to serve in the Turkish-officered armies of the Ottoman Empire. In exchange for these services the Turks treated the Arabs with contempt, administered harsh justice, and were always ready to mete out cruel punishment. And yet, in retrospect, the memory of the fourcenturies-long cruel Turkish rule evokes in the Arabs much less resentment and hate than the memory of the one-hundred-year-long European domination which, in comparison, was humane and enlightened.

"One reason for this undoubtedly lies in the religious identity between Turks and Arabs. The Turkish sultan was not only the temporal head of the Ottoman Empire, but also the caliph, the religious head of all Sunnî Islam. Whether or not the Arabs liked to see the caliphate held by a Turkish sovereign, he still was in their eyes the caliph, the legitimate successor of the Prophet Muhammad, to whom obedience was due. Whatever injustices and cruelties were committed against the Arabs by the officers of the Turkish government and army, the Sultan-Caliph as the symbol of Islam could not and was not held culpable. This also meant that the hate felt by the Arabs against individual Turkish potentates, such as the notorious Ahmad Pasha, surnamed al-Jazzâr, "the butcher," the despotic ruler of Syria and Lebanon for many years, was, as a rule, not generalized and extended to all the Turks. While the name of al-Jazzar, who died in 1804, still lives "as a synonym of terror and cruelty," the hatred of the Turks in general, even if it was intense during their misrule over the Arab lands, has long become a thing of the past.

"As against this, the European powers were Christian. And Christians were for the Arabs an undifferentiated human conglomerate, the infidel enemy. For the untutored mind which was always the great majority in the "House of Islam," all Christendom was one: moreover, every group of Christians was considered to be a typical representative of all "Franks," that is, Christians. The very circumstance that the people who from the nineteenth century on -managed to establish themselves as the new masters of the Arabs were Christians made it almost inevitable that the Arabs should generalize their animosity and make all Christendom, or the entire West, the object of their resentment and hatred. Every individual act of aggression, every particular injustice, real or imagined, was considered as expressive of what the Christian West as a whole stood for and became an added irritant exacerbating and embittering the Arabs' attitude to the West. 
"Another point is the different historical experiences the Arabs had with Turkey on the one hand and with the West on the other. It is a psychological law that people nurture a greater hatred toward those who have been their inferiors in the past and then succeed in outdistancing them, than toward those who proved their superiority from the very first moment of their encounter. As far as the Arabs are concerned, the Turks belong to the latter, the West to the former category. Ever since the Ottoman Turks established their rule in Anatolia (after 1300), the Arab-Turkish encounters always spelled defeat for the Arabs and victory for the Turks. After a short period of indecisive rivalry between the Turkish and the Egyptian sultan in the late fifteenth and early sixteenth centuries, expressed in repeated conflicts on the borders between Asia Minor and Syria, the Turks conquered Syria in 1516 and Egypt the following year. Thereafter, for more than three centuries, until the rise of the European colonial powers, the Turks were in Arab eyes the invincible champions of Islam, who, it is true, bore down heavily with their feet on Arab necks, but who also brought down on Christian necks the victorious sword of Muhammad. Such an overlord an Arab may resent, and attempt to rebel against, but he certainly cannot hate him as intensively as he can the infidel Christian.

"The outcome of the early encounters between Christians and Arabs was, as a rule, Christian defeat. This engendered a feeling of superiority in the Arabs, with a complementary feeling of disdain for the Christian. When the Arabs conquered lands ruled by Christians, and allowed the Christian remmants to live in the midst of the Muslims as dhimmis, or protected, second-class citizens, this disdain grew into contempt. For centuries no Christian power was a match for the Muslim Arabs. The limits of the Arab expansion were set less by Christian armies than by natural obstacles. When the tide turned and the Arabs were gradually pushed back by Christian Europe, and especially when, from 1798 on, Christian Europe began to make inroads into Arab lands, the haughty disdain the Arabs had nutured toward Rum (Christendom) became transformed into impotent rage, and ultimately into fierce hate.

"Here, thèn, was a classical example of group hatred intensified by the historical reversal of a power relationship. What cannot be forgiven the rival outgroup is not so much the fact that it has gained the upper hand, as the circumstance that it managed to do so after it had for long been forced to play the role of the underdog. No comparable reveral of historical roles has occured on a worldwide scale between any other two cultures."*

- Patai, Raphael, The Arab Mind, Charles Scribner's Sons, New York, 1883, P. 301-303. 
These qotations contain so many mistakes, historically and methodologically that it is not easy to know where to start. The value oriented approach should be left out here as not the subject of this paper: A few historical facts however should not be left out.

The first is about the 'Turks' bleeding the Arab land white'. The Arabs, all through Ottoman history were considered the kavm-1 necib or the noble tribe because the Prophet was an Arab. They were sheltered by the administration both in military and in civil life. The rule of harsh administrators were as effective among Turks as they were among Arabs. In fact the Ottomans considered Turks as etrak-1 bi idrak or the ignorant Turk. If a land really bled under the Ottoman rule, through serving in the armies and paying taxes, it was Anatolia.

The second is Arabs losing against the Turks every time. Leave history aside, should they not have won at one time to be able to convert the Turks to Islam?

A third point is about Christians under Islamic rule, the zimmis (dhimmis). All through its history, Islam, contrary to many other religions, did not force people of other religions to convert to Islam. These were left to live in peace in the Land of Islam (Dar ül-Islam). These however had to be one of the religions recognised by the Quran, namely, Christians, Jews and Mazdeists. So, even when people were being massarced in Spain only because they belonged to the Islamic Religion, in Islamic land, those of other religions were left to keep their own practices.*

Let the reader however, for methodological reasons, consider Patai's statements true. A reavaluation of the same historical period becomes. necessary.

"The main theme of governing the people the Ottoman Empire was. obedience to the rules of religion, that is, religion was the centerpiece of the State mechanism of the Ottoman Empire. The subject were considered as "ummet" or the "flock of the religion." The sultan was also the caliph, and thus both their temporal and spiritual leader. The Sharia covered both the social and religious life. "In other words, Iślamic Sharia is both divine and social". Thus in the Ottoman State, the Caesar's and God's. belongings were united and the Judge, 'kadi' was also [a] ... religious. authority... We can say that the Caliph-Sultan and the Ummet relationship was effective when it was, not purely for religious reasons but also for being part of the culture of the society."***

* Uçok, Coşkun, Ahmet Mumcu, Türk Hukuk Tarihi, AÜHFY, Ankara, 1976, p. 63-64.

* Seker, Murat. Can Law Be an Agent of Social Change, A.U. Siyasal Bilgiler Fakültesi Dergisi, Cilt XXXIX, Sayı 1-4, 1984, P. 94. 
Thus, for a synchronised answer to Patai's problem, rather than using his anachronism, the reader should consider the social structures of the societies of the mentioned period to be able to understand the relation of the West and the Arabs and compare it to the relationship of the Turks and the Arabs.

H.G. Barnet, in his book titled Innovation: The Basis of Cultural Change, states that, "competition can also lead to imitation... In order to reach a goal competitors often adopt the methods of each other... the borrowed object or technique is inevitably mdified in the process of imitation... The industrial ideal that Japan adopted from the United States under the stimulus to compete with Western world were altered to fit Japanese standards. Similarly for the westernization of Turkey. Kemal Atatürk felt the nos to bring his country into the orbit of western Europe in order to maint $n$ its life as a nation to be reckoned with in world councils..."* While the author of this paper lacks the information on the Japanese side, on the Turkish side, the goal was not imitation for competition but basically innovation. Here is an example of taking one's own social values, namely, the American understanding of competition and imitation, and labeling the facts in another country as such.

One last example is derived from D.H. Dwyer's work about Moroccan Women. The author in her work, examines male-female relationship in Morocco working mainly on existing laws. She states that:

"Although some restrictions have been ameliorated, essential aspects of women's subordination remain. Men hold the right to keep their women secluded to prohibit them from joining the labor force, and to restrict their social contacts. Men also have the privilege of taking additional wives (up to four) and divorcing their wives at will. At best,. women can pressure their men to lessen these disabilities individually, by using their sexuality and by wielding their power over their children.

"One source of men's power over women resides in the law, as it is articulated in statute, and in the practices which have developed about it. Moroccan statutes and edicts define a system of female subordination in three ways: by limiting women's physical mobility, their social interactions, and their sexual contacts. According to regional administrative fiat, there are certain hours during which women should not appear in public, and numerous places in which they should not be found without permission. According to national statute, there are only a very few persons with whom interaction is guaranteed, and there is only one male,

* Mc Graw-Hill, 1953, P. 76. . 
the husband, with whom sexual contact is permitted. Male household heads have discretionary rights to grant their women greater freedoms. They also have the right to delegate these powers, their mothers often being accorded the task of supervising wives and daughters when men are not present.

"Mobility, sociality, and sexuality are fundamental components of life, and women logically show a lively interest in regulations relating to them. Men also show their concern with this aspect of supervision, for they view women as untrustworthy and threatening. As a result, both sexes are involved in an active and dynamic exchange regarding these laws. Women typically accept them on the surface, while also seeking to evade them by finding and exploiting legal loopholes. Men seek to promote them with an ever greater stringency. The interchange and conflict generated by these strategies is the focus of the remainder of this paper. Laws and practices relating to women's curfews, to marriage and divorce, and to the rules governing female virginity are examined as illustrations of the three primary arenas of female subordination: mobility, sociality, and sexuality...

"Beliefs about local curfew regulations vary. Women and girls share one set of beliefs, which construe limitations stringently; these beliefs form a working basis for a wide range of self-restricting behaviors. Men who are not working in law enforcement tend to hold another view, which typically they do not transmit to their womenfolk. As a third group, town officials exhibit a knowledgeability about the town curfew, as an ideal and real system, that combines with a cynicism regarding the paucity of knowledge which other men, and especially women, hold.

"Women's beliefs about curfew naturally is fed upon the constraints that they feel it imposes on their physical mobility and social contacts. Women in one southern Moroccan town state that any woman or girl who is "caught out" in the streets after sunset is liable to detention by the police. To them, detention is a particularly frightening occurrence: it consists of remaining overnight in the local police station in the presence of police officers who, being men, are apt to take sexual advantage. By the time a woman's family is contacted the next day, either to swear to her respectability or to pay the fine needed to release her, the detained woman's reputation, women say, is irretrievably lost.

"Because of the threat that police detention poses, curfew is a serious matter. In the course of any month, women's' conversation turns increasingly to the curfew as the probability of a police raid increases. It is known that once a month, or perhaps twice, the police take to the streets 
and bring in curfew breakers of three kinds. Women are rounded up, with a particular emphasis upon prostitutes working the town's more notorious streets. Young boys, who are regarded as likely to carouse, smoke, and plifer in what is viewed as a life of insufficient responsibility, are also apprehended. Adult male residents, whose nighttime business in the city is interpreted by women as the frequenting of prostitutes, whether the latter are professional or not (an ostensibly reputable woman who gives her sexual favors to a man who is not her husband is considered a prostitute and can be so charged by law), are also subject to detention. But the consequences for a woman apprehended in such a raid are much more serious than for either young boys or adult males.

"The reality of monthly police raids encourages much complex strategy building by women. The town's womenfolk spread the news quickly when the police paddywagons appear. Women who find themselves in others' houses during a police raid consider ways to avoid arrest upon leaving. Several premises emerge from their discussions about appropriate strategies. First, the upstanding woman does not regard her good reputation as sufficient to protect her against the police: such women will sometimes chart out pathways through back alleys so that the police will not stop them on the way home, and sometimes will consider staying at acquaintances' homes for the night if their menfolk are willing. Second, women do not find protection in traveling together: women who are attending a wedding sometimes will venture home as a bloc in the early morning of a seizure night, but they consider their festive dress and joyful demeanor more of a shield than the clustering of female bodies. Third, women recognize the potential role of children as "morals guardians" in such situations; indeed, the presence of children may become the primary safeguard for preversing their reputations. The children of a hostess may be "borrowed" to accompany a woman home on a raid night, and a hostess without children may borrow those of a neighbor to accompany female guests. Children recruited for this task may then remain overnight with the accompanied woman's family, or may sneak home in the fashion of other children. Overnighting is viewed as the safer route, for the curfew is also operative on minors. Clearly, women believe that children "in tow" provide a valid defense before the police and the courts, and men are expected to eccept this tactic as evidence of women's respectability.

“These strategies reval much about women's assumptions concerning how chaos and order are generated and hence what effective laws should contain. Women, for example, know that the reputable woman who seems to be coming from the public bath, bucket in hand, or from a friend's home after the tea hour, might actually be returning from a itryst wih a 
lover. Similarly, the presence of a sister or friend might also serve as a camouflage for an illicit affair, for women exhibit a certain degree of solidarity. Only a woman who is in the presence of a child, women say, will be unlikely to indulge her wantonness because of the instinctual maternal commitment which lasts at least through the moments of the child's physical presence. One might add that children readily tattle on their elders for a price, a reality which makes one cautious in their presence...

"The typical male view appears to be the more informed one. Police assert that they do not detain reputable women, although they occasionally intimidate them through a word or glance. They tend to concentrate upon the prostitutes of the town's red-light districts. These women are known by face, dress, and demeanor and are quickly escorted to the police station when they are found in the streets. Once brought to the station, these women are held separately from male curfew violators, who are fined or, if poor, made to donate blood to the local hospital. The prostitue's lot, police say, is easier than the male curfew violator's, for prostitues are not required to give blood and are generally excused upon first arrest: policemen say that they and the courts display greater leniency to women of any kind and cite Islamic dogma as condoning this practice." ${ }^{\text {n* }}$

Going into to Dwyer's research, the mentioned limitations upon women are, seclusion, work prohibitation and restriction of social contacts. Dwyer, sees the law as the main cause of these restrictions. This law restricts the physical mobility, social interaction and free sexual contact of Moroccan Women.

The author of this paper is convinced that, Dwyer, has her own country's norms with her, all through the research. To synchronise the norms of her country with the norms of Morocco, a mirror must be held back to America.

The behavior of both husband and wife are mutually controlled in every country within their countries' social structures. This is so for seclusion and work prohibitation too. So, a Moroccan Woman going out without covering her hair may be similar to the American Woman who goes shopping in her bikinies. As for work prohibitation, the author of this paper has heard many times the current American Administration's theories about working women being the cause of unemplayment in America.

* Dwyer, Daisy Hilse, Law Actual and Perceived: The Sexual Politics of Law in Morocco, Law and Society Review, Vol. 13, No. 3: 739-56, 1979, P. 742-746. 
The author now invites the reader to a seemingly different area, to question the American Prostitute. While working on the feasibility of a research about the American Prostitute, the author was able to find some facts about them:

During the work, police and prostitute relations were investigated in the Citiy of Oakland in California. The prostitutes in Oakland "work" the street of San Pablo. They are recognised as wearing tight jeans. Every now and then, the Oakland Police will, without asking questions raid the San Pablo Street, round up tight-jean-wearing women, detain and 'lecture' them.

The ignorant reader must be warned that these are unconstutional procedures for America.

What is happening here is that, the police find it their duty to fight prostution (quite correctly of course); they identify prostitutes from * their dresses; and they remove them from public places to detain.

Reading Dwyer's paper, we can conclude that, Moroccan police find it their duty to fight prostution (and they should be right in doing so too); they identify prostitutes from their dresses; they remove them from public places to detain.

Identification, places, times and methods differ in both countries, both police forces have probably obtained these from years of expertise, but probably both police forces sometimes make mistakes and detain innocent women.

Thus we are enabled a synchronised comparison on these matters. Another point has to be made about the pover or the weakness of law. Laws only reflect a country's social structure. They can only effect a country and a society through being a part of that social structure. In other words laws are never autonomous, but wery much related and united to the society. In Morocco, laws prohibiting women from sexual intercourse with people other than their husbands are not unbound to the society itself. Thus, Morocco could pass a dozen laws or even put it in her constitution that women are free in their sexual life but all these laws would not affect the behavior patterns of Moroccan Women at, all.

Another point is about Islamic Women. This ongoing clamor about the "suppressed Islamic Women" depands upon doubtfull research. The author is convinced about the necessity of further research by scholars without value orientations. 
In conclusion, while working in another country with a totally different culture, a researcher must be very carefull in his or her observations. Social research is not easy. Researches carried out with a hit-andrun technique are liable to float in the air never to reflect the solid truth.

\section{BIBLIOGF.APHY}

Barnet, H.G., Innovation. The Basis of Cultural Change, Mc Graw-Hill, 1953.

Dwyer, Daisy Hilse, Law Actual and Perceived: The Sexual Politics of Law in Morocco, Law and Society Review, Vol. 13, No. 3: 739-746.

Jennings, M. Anne, The Victim as Criminal: A Consideration of Califoria's Prostitution Law, California Law Review, 64: 5, Sept. 1976.

Malinowski, Bronislaw, The Dynamics of Culture Change, Yale University Press, 1961.

Mead, Margaret (Ed.), Cultural Patterns and Technical Change; New American Library, 7th printing, 1962.

Patai, Raphael, The Arab Mind, Charles Scribner's Sons, New York, 1983.

Seker, Murat, Can Law Be an Agent of Social Change, A.U. Siyasal Bilgiler Fakültesi Dergisi, Cilt 39, Sayı 1,4, 1984.

Şenel, Adam (Alaaddin), Sağcı Düşünüşün Kritik Tarihi, Doğan Yayınevi, 1868.

Shakespeare, William, Julius Caesar, H.M. Hulme (Ed.), Green and Co. Ltd., London, 2nd Printing, 1965.

Sko'nick, Jerome H., Justice Without Trial, John Wiley and Sons, Inc., 1966.

Ucok, Coşkun, Ahmet Mumcu, Türk Hukuk Tarihi, A.U. Hukuk Fakültesi Yayın, Ankara, 1876. 